\title{
Food contamination with salmonella and human health in Kinshasa city, Democratic Republic of Congo (DRC)
}

\author{
Mahangaiko M1; Mabi N2; Bakana M2; Nyongombe U2. \\ 1. University of Lubumbashi, BP 1825 Lubumbashi Katanga, Democratic Republic of Congo \\ 2 Université Pédagogique Nationale de Kinshasa, Route de Matadi/Avenue de la Libération, Quartier Binza/UPN B.P. \\ 8815Kinshasa Democratic Republic of Congo, Corresponding Author: mahangaikofr@yahoo.fr
}

Original submitted in on $6^{\text {th }}$ August 2015. Published online at www.m.elewa.org on 31st October 2015

http://dx.doi.org/10.4314/jab.v94i1.3

\begin{abstract}
Objectives: The objective of this study was to assess the level of salmonella contamination of fish and meat from public markets, meat from butcheries and beef carcasses offered for retail sale in Kinshasa, the capital city of the Democratic Republic of Congo

Methodology and results: Salmonella spp. in fish and meat was isolated using the classical technique with a pre-enrichment, enrichment, isolation and identification. The mean number of colonies counted was expressed as $\log _{10}$ colony forming units per gram $(\log 10 \mathrm{cfu} / \mathrm{g})$. The prevalence of Salmonella contamination was $11.1 \%$ for fish, $18.3 \%$ for meat from public markets, $14.4 \%$ for meat from the butcheries and $27.5 \%$ for beef carcasses at the public abattoir. The positive rate in the evening was higher than in the morning $(p<0.05)$. The bacterial loads ranged from $2.48-9.84 \log _{10} \mathrm{cfu} / \mathrm{g}$.

Conclusions and applications: This study revealed salmonella contamination of fishes and meats offered for retail sale in Kinshasa city. The contamination was higher in the evening than in the morning. Salmonella are pathogenic microorganisms significant in food infection and intoxications. Results from this study indicate that the food hygiene is poor demonstrating the importance of controlling this pathogen in food processes
\end{abstract}

Key words: Salmonella, meat, retail sale, abattoir, Democratic Republic of Congo

\section{INTRODUCTION}

Most developing countries are faced with high incidences of food poisoning outbreaks. Food borne diseases remain an important public health problem worldwide and one of the most significant food safety hazards associated with foods from animals (Maripandi and Al-Salamah, 2010). Meat is one of the most consumed foods in the Democratic Republic of Congo in general and the city of Kinshasa in particular. However, meat is the most perishable of all staple foods since it contains sufficient nutrients needed to support the growth of microorganisms (Huda et al., 2010). In the Democratic Republic of Congo, meat is sold at a retail level to the public on open markets (Fig. 1) and kept exposed making it naturally vulnerable to infection with different types of microorganisms such as Salmonella. Salmonellosis is an important public health problem causing substantial morbidity, and thus having a significant economic impact. Although most infections cause mild to 


\section{Mahangaiko et al. J. Appl. Biosci. 2015 Food contamination with salmonella and human health in}

Kinshasa city, Democratic Republic of Congo (DRC)

moderate self-limited disease, serious infections leading to death do occur (Laconha et al., 2000; Birgitta de Jong and Ekdah, 2006).

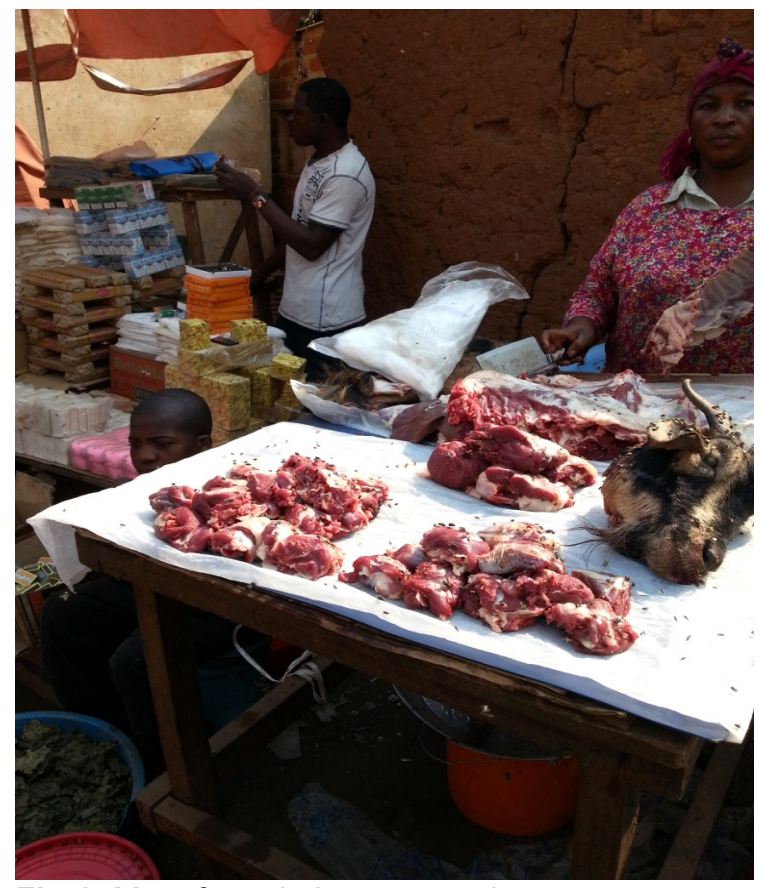

Fig 1: Meat for sale in open market

In the last years, global surveillance data indicated that the incidences of salmonellosis has increased mainly associated with the consumption of raw or undercooked eggs, poultry, meat or dairy products (Katayama et al., 2013; Samiullah, 2013), demonstrating the importance of controlling this pathogen in food processes. In the developed world, salmonellosis due to $S$. Enteritidis is most often associated with consumption of poultry and eggs (Stojanović et al., 2010). They are relatively

\section{MATERIALS AND METHODS}

Material and sampling: Seventy-two samples of fresh fish, 120 samples of meat (beef, pork, mutton, goat and chicken meat) were randomly selected from public markets in Kinshasa. Eighty-for samples of meat (beef, pork and chicken meat) were also selected from butcheries and 40 samples of beef carcasses from the public abattoir. All samples were collected from 20102011. Fishes collected were Tilapia, Mackerel, Catfish, Roach fish, Common carp and Bleak fish. Fish and meat samples from retail markets and butcheries were collected $50 \%$ in the morning $(8.00-9.00 \mathrm{am})$ and 50 few surveys and lack of information on the bacteriological status of meat sold in Kinshasa and the level of hygiene of the public abattoirs in the Democratic Republic of Congo. Several food borne outbreaks linked to Salmonella were attributed to meat and poultry (Thomas et al., 2006). Salmonellosis is the disease caused by Salmonella serovars. A few serotypes are host-specific like Salmonella typhi for typhoid fever in human beings. However, the others are not host-specific and may infect several animal species including human beings. These serotypes are generally responsible for food borne diseases such as nausea, intestinal cramps, diarrhoea, vomiting and possible arthritic symptoms. These diseases are treatable (Coburn et al.,2007, Neto et al., 2010). The presence of Salmonella infections such as typhoid fever caused by Salmonella typhi is a major public health concern in the Democratic Republic of Congo. In December 2004, there was an outbreak of typhoid fever in Kinshasa, the capital city of the Democratic Republic of Congo. A total of 13400 cases were reported. Between 1 October and 10 December 2004, 615 severe cases with peritonitis, with or without perforation, including 134 deaths have occurred (WHO, 2004). The aim of this study was to assess the level of salmonella contamination of fish and meat from public markets, meat from butcheries and beef carcasses offered for retail sale in Kinshasa, the capital city of the Democratic Republic of Congo.

$\%$ in the evening (4.00 -5.00 pm). Samples were kept in separate sterile plastic bags, stored in cool boxes and transported to laboratory on the same day of sample collection.

Microbiological assays: Twenty-five Grams of meat were cut into small pieces before being added to a stomach bag containing $225 \mathrm{~mL}$ of buffered peptone water (BPW). The $1 \mathrm{~mL}$ of the homogenate was serially diluted in an aseptic condition and used for the enumeration of microorganisms. Salmonella spp. were isolated using the classical technique with a pre- 


\section{Mahangaiko et al. J. Appl. Biosci. 2015 Food contamination with salmonella and human health in Kinshasa city, Democratic Republic of Congo (DRC)}

enrichment on buffered peptone water (Oxoid CM 509), enrichment into Rappaport Vassiliadis Broth (Merck 1.07700), isolation on Salmonella-Shigella Agar (Merck 1.07667) and identification with the API $20 \mathrm{E}$ (Biomérieux, France). The mean number of colonies

\section{RESULTS}

Salmonella contamination of fish samples from public markets: A total of 72 fish samples were collected and among which 8 positive. The positive rate was $11.1 \%$ (Table 1). All fish species were contaminated except Tilapia and bleak fish. The highest counted was expressed as $\log _{10}$ colony forming units per gram $(\log 10 \mathrm{cfu} / \mathrm{g})$.

Statistical analysis: The Chi-square test were used to compare the prevalence of salmonella contamination between samples collected in the morning and those collected in the evening $(p=0.05)$.

number of Salmonella was found in roach fish sold in the evening $\left(6.95 \log _{10} \mathrm{cfu} / \mathrm{g}\right)$.There was no significant difference between the prevalence of Salmonella contamination in the morning and the evening (Table 5).

Table 1: Results of Salmonella in fishes

\begin{tabular}{|c|c|c|c|c|c|}
\hline Species & Time & $\mathrm{n}$ & Positive & $\begin{array}{c}\text { Positive rates } \\
(\%)\end{array}$ & $\begin{array}{l}\text { Mean counts } \\
\left(\log _{10} \mathrm{cfu} / \mathrm{g}\right)\end{array}$ \\
\hline Tilapia sp & $\begin{array}{l}\text { Morning } \\
\text { Evening }\end{array}$ & $\begin{array}{l}6 \\
6\end{array}$ & $\begin{array}{l}0 \\
0\end{array}$ & $\begin{array}{l}0 \\
0\end{array}$ & $\begin{array}{l}0 \\
0\end{array}$ \\
\hline Mackerel & $\begin{array}{l}\text { Morning } \\
\text { Evening }\end{array}$ & $\begin{array}{l}6 \\
6\end{array}$ & $\begin{array}{l}1 \\
2\end{array}$ & $\begin{array}{l}16.7 \\
33.3\end{array}$ & $\begin{array}{c}2.48 \\
3.73 \pm 2.45\end{array}$ \\
\hline Cat fish & $\begin{array}{l}\text { Morning } \\
\text { Evening }\end{array}$ & $\begin{array}{l}6 \\
6\end{array}$ & $\begin{array}{l}1 \\
1\end{array}$ & $\begin{array}{l}16.7 \\
16.7\end{array}$ & $\begin{array}{l}5.48 \\
4.30\end{array}$ \\
\hline Roach fish & $\begin{array}{l}\text { Morning } \\
\text { Evening }\end{array}$ & $\begin{array}{l}6 \\
6\end{array}$ & $\begin{array}{l}1 \\
1\end{array}$ & $\begin{array}{l}16.7 \\
16.7\end{array}$ & $\begin{array}{l}4.48 \\
6.95\end{array}$ \\
\hline Common carp & $\begin{array}{l}\text { Morning } \\
\text { Evening }\end{array}$ & $\begin{array}{l}6 \\
6\end{array}$ & $\begin{array}{l}1 \\
0\end{array}$ & $\begin{array}{c}16.7 \\
0\end{array}$ & $\begin{array}{c}5.30 \\
0\end{array}$ \\
\hline Bleak fish & $\begin{array}{l}\text { Morning } \\
\text { Evening }\end{array}$ & $\begin{array}{l}6 \\
6\end{array}$ & $\begin{array}{l}0 \\
0\end{array}$ & $\begin{array}{l}0 \\
0\end{array}$ & $\begin{array}{l}0 \\
0\end{array}$ \\
\hline TOTAL & & 72 & 8 & 11.1 & \\
\hline
\end{tabular}

Results of Salmonella in meats and beef carcasses: Meats from public markets were contaminated with Salmonella and the positive rate was $18.3 \%$ (Table 2). Mutton was more contaminated $(50 \%)$ than all other meats followed by pork (41.7\%). Meats sold in the evening were more contaminated than those sold in the morning were $(p<0.05)$ (Table 5). The highest number of Salmonella was found in pork ( $\left.8.30 \log _{10} \mathrm{cfu} / \mathrm{g}\right)$. From the butcheries, 84 samples of beef, pork and chicken were collected with a positive rate of $14.3 \%$ (Table 3). There was no significant difference between the prevalence of Salmonella contamination in the morning and the evening (Table 5). The chicken meat was less contaminated than other meats. The prevalence of Salmonella contamination for beef carcasses at the public abattoir was $27.5 \%$ (Table 4 ) with a mean value of $5.76 \pm 2.71 \log _{10} \mathrm{cfu} / \mathrm{g}$.

Table 2: Results of Salmonella in meat from public markets

\begin{tabular}{|l|l|l|l|l|l|}
\hline Species & Time & $\mathbf{n}$ & Positive & $\begin{array}{l}\text { Positive rate } \\
(\%)\end{array}$ & $\begin{array}{l}\text { Mean counts } \\
\left(\log _{10} \text { cfu/g) }\right.\end{array}$ \\
\hline Beef & Morning & 12 & 1 & 8.3 & 6.70 \\
& Evening & 12 & 2 & 16.7 & $6.85 \pm 0.21$ \\
\hline Goat meat & Morning & 12 & 0 & 0 & 0 \\
& Evening & 12 & 4 & 33.3 & $6.25 \pm 2.03$ \\
\hline Mutton & Morning & 12 & 0 & 0 & 0 \\
& Evening & 12 & 6 & 50 & $7.66 \pm 1.02$ \\
\hline Pork & Morning & 12 & 1 & 8.3 & 8.30 \\
\hline
\end{tabular}


Mahangaiko et al. J. Appl. Biosci. 2015 Food contamination with salmonella and human health in Kinshasa city, Democratic Republic of Congo (DRC)

\begin{tabular}{|l|l|l|l|l|l|}
\hline & Evening & 12 & 5 & 41.7 & $6.66 \pm 2.04$ \\
\hline Chicken meat & Morning & 12 & 0 & 0 & 0 \\
& Evening & 12 & 3 & 25 & $6.90 \pm 1.42$ \\
\hline TOTAL & & 120 & 22 & 18.3 & \\
\hline
\end{tabular}

Table 3: Results of Salmonella in meats from the butcheries

\begin{tabular}{|l|l|l|l|l|l|}
\hline Species & Time & $\mathbf{n}$ & Positive & $\begin{array}{l}\text { Positive rate } \\
(\%)\end{array}$ & $\begin{array}{l}\text { Mean counts } \\
\left(\log _{10} \text { cfu/g) }\right.\end{array}$ \\
\hline Beef & Morning & 14 & 1 & 7.1 & 7.70 \\
& Evening & 14 & 4 & 28.6 & $6.91 \pm 0.59$ \\
\hline Pork & Morning & 14 & 3 & 21.4 & $7.93 \pm 0.33$ \\
& Evening & 14 & 3 & 21.4 & $8.11 \pm 1.22$ \\
\hline Chicken meat & Morning & 14 & 0 & 0 & 0 \\
& Evening & 14 & 1 & 7.1 & 6.48 \\
\hline TOTAL & & 84 & 12 & 14.3 & \\
\hline
\end{tabular}

Table 4: Positive rate and mean values of Salmonella in beef carcasses at the public abattoir

\begin{tabular}{|l|l|}
\hline $\mathrm{N}$ & 40 \\
\hline Positive & 11 \\
\hline Positive rate & $27.5 \%$ \\
\hline Mean value $\left(\log _{10} \mathrm{cfu} / \mathrm{g}\right)$ & $5.76 \pm 2.71$ \\
\hline Min & 2.60 \\
\hline Max & 8.60 \\
\hline
\end{tabular}

Table 5: Prevalence of Salmonella contamination for fishes and meats in the morning and the evening

\begin{tabular}{|l|l|l|l|l|}
\hline Variable & Time & $\mathrm{N}$ & Positive & Positive rate (\%) \\
\hline Fish & Morning & 36 & 3 & $8.3^{\mathrm{a}}$ \\
& Evening & 36 & 5 & $13.9^{\mathrm{a}}$ \\
\hline Meat from markets & Morning & 60 & 2 & $3.3^{\mathrm{a}}$ \\
& Evening & 60 & 20 & $33.3^{\mathrm{b}}$ \\
\hline Meat from butcheries & Morning & 42 & 4 & $9.5^{\mathrm{a}}$ \\
& Evening & 42 & 8 & $19^{\mathrm{a}}$ \\
\hline
\end{tabular}

Prevalence with the same letter in the same category sample is not significantly different at $5 \%$

\section{DISCUSSION}

Across the world, food contamination by pathogens is a health concern to consumers as well as for several governments (Birgitta de Jong and Ekdah, 2006). The search of Salmonella, microbe responsible for food poisoning and gastroenteritis in humans becomes a priority for many nations (Dobrinas et al., 2014). In this study, 72 samples of six species of fish from public markets in Kinshasa revealed the prevalence as $11.1 \%$. All markets were contaminated. This result for Salmonella contamination in fish samples $(11.1 \%)$ was in close agreement with that of Qiumey et al., (2012) who reported that $10 \%$ of fish samples were contaminated with Salmonella $s p$. in Shanghai province. These studies showed also that all types of meat from the markets as well as from the butcheries were contaminated (Table 2 and Table 3 ) with a positive rate of $18.3 \%$ and $14.3 \%$ respectively. These products, according to many reports, are the sources of Salmonella contamination (Vindigni et al., 2007; Ghimire et al., 2013; Dobrinas et al., 2014). In the markets, retail mutton and pork were highly contaminated. The prevalence of Salmonella contamination in retail mutton, pork, goat, beef and chicken meat from the market were $25 \%(6 / 24), 25 \%$ (6/24), 16.7\% (4/24), 12.5\% (3/24) and $12.5 \%(3 / 24)$ respectively. The prevalence of Salmonella in retail pork and chicken meats in this work was less than that reported by Lertworapreecha et al. (2013) from retail markets in Phatthalung Province, Thailand. In the public markets, the prevalence of Salmonella contamination 
was $11.1 \%$ (8/72) for fish and $18.3 \%$ (22/120) for meat but there was no significant difference $(p>0.05)$ between the prevalence of Salmonella contamination for fish and meat. According to Erdogrul and Bulbul (2006), Salmonella microorganism is rarely seen in fish. However, it could reproduce upon the contamination from the environment. Previous studies examining the presence of Salmonella reported that different fish species could be contaminated with Salmonella $s p$. (Erdogrul and Bulbul, 2006; Akaki et al., 2012). Of 120 meat samples collected from the markets, 60 were collected in the morning with a positive rate of $3.3 \%$ $(2 / 60)$ and 60 in the evening with a positive rate of $33.3 \%(20 / 60)$. The positive rate in the evening was higher than in the morning $(p<0.05)$. These results showed increased environmental contamination and reflect poor condition and unhygienic practices (Adetunji and Isola, 2011). At the public abattoir, the prevalence of Salmonella in beef carcasses was $27.5 \%$ (11/40). The number of Salmonella was ranging from

\section{CONCLUSION}

This study revealed salmonella contamination of fishes and meats from the public markets, butcheries and abattoir. The presence of Salmonella in fishes and meats, which are pathogen microorganisms significant for food infection and intoxications, are highly important

\section{REFERENCES}

Adetunji VO and Isola TO, 2011. Enumeration of Listeria and Enteric bacteria of public health significance on meat in Ibadan municipal abattoir Nigeria. Pak. J. Nutr., $10: 224-228$.

Akaki KD, Sadat AW , Coulibaly K, 2012. Bacteriological Study of Grilled Fish Consumed in Yamoussoukro Commune, Political Capital of Côte d'Ivoire. Curr. Res. J. Biol. Sci., 4: 297-300.

Birgitta de Jong and Ekdahl K, 2006. The comparative burden of salmonellosis in the European Union member states, associated and candidate countries. BMC Public Health, 6: Pp 4

Coburn B, GrassI GA, Finlay BB, 2007. Salmonella the host and disease: A brief review. Immunol. Cell Biol., 85:112-118.

Dobrinas S, Soceanu A, Popescu V, Staniu G, Suliman S, 2014. Quality control of some traditional meat products. St. Cerc. St. CICBIA,14: 29-40.
$2.60-8.60 \log _{10} \mathrm{cfu} / \mathrm{g}$. This result was in agreement with those of Gormley et al. (2010); Koffi-Nevry et al. (2011) indicating that the contamination with bacterial pathogens occurred earlier in the production chain. In this study, the presence of Salmonella sp. was indicative of poor hygiene and a potential danger to consumers. Therefore, Salmonella sp. in foods constitutes a significant risk can be used as an indication of cross-contamination as emphasized by other reports (Mattick et al., 2002; Maharjan et al., 2006). Numerous studies have demonstrated how pathogens can be effectively distributed around the environment and back to food in the absence of strictly observed hygiene guidelines ( Onenyeho and Hedberg, 2013 ; Redmond and Griffith, 2003 ). The high-risk human population, which is infants, elderly, immunocompromised and malnourished persons are highly susceptible and the presence of Salmonella even in low numbers constitutes a major public health concern (Dominguez et al., 2002; Molla et al., 2003).

for public health. Results from this study indicate that the food hygiene should be improved. In addition, the specific salmonella a species needs to be researched into for better prevention of the disease.

Dominguez C, Gomenz I, Zumalacarregui J, 2002. Prevalence of Salmonella and Campylobacter in retail chicken meat in Spain. Int. J. Food Microbiol., 72: 165-168.

Erdogrul $\mathrm{O}$ and Burbul O, 2006. The hygienic properties of Acanthobrama marmid and Kahramanmaras fish markets. J. Sci. Eng., 9: 41-45.

Ghimire L, Dhakal S, Pandeya YR, Chaulagain S, Mahato BR, Satyal RC, Singh DK, 2013. Assessment of pork handlers' knowledge and hygienic status of pig meat shops of Chitwan district focusing campylobacteriosis risk factors. Int. J. Infect. Microbiol., 2: 17-21.

Gormley FJ, Little CL, Grant KA, De Pinna E, McLauchlin J, 2010. The microbiologic safety of ready-to-eat specialty meats from markets and specialty food shops: A UK wide study with a focus on Salmonella and Listeria monocytogenes. Food Microbiol., 27:243-249.

Huda N, Shen YH, Huey YL, Ahmad R, Mardiah A, 2010. Evaluation of physico-chemical 
properties of Malaysian commercial beef meatballs. Am. J. Food Technol., 5: $13-21$.

Katayama ER, Donato TC, Silva A de P, Mazola RP, Garcia EA, Okamoto AS, Andreatti Filho RL, 2013. Salmonella enteritidis in the eggs of Japanese quails fed diets with different calcium and phosphorus levels. Rev. Bras. Cienc. Avic. 15: $27-30$.

Koffi-Nevry R, Koussémon M, Coulibaly SO, 2011. Bacteriological quality of beef offered for retail sale in Cote d'Ivoire. Am.J.Food Technol., 6 : 835-842.

Laconha I, Baggesen DL, Rementeria A, Garaizar J, 2000. Genotypic characterization by PFGE of Salmonella enterica serotype Enteritidis phage types1, 4, 6, and 8 isolated from animal and human sources in three European countries. Vet. Microbiol., 75: 155-165.

Lertworapreecha M, Sutthimusik S, Tontikapong K, 2013. Antimicrobial resistance in Salmonella enterica isolated from Pork, Chicken and Vegetables in Southern Thailand. Jund. J. Microbiol., 6: 36-41.

Maharjan M, Joshi V, Joshi DD, Manandhar P, 2006. Prevalence of Salmonella species in various raw meat samples of a local market in Kathmandu. Ann N Y Acad Sci., 1081: 249256.

Maripandi A and Al-Salamah AA, 2010. Multipleantibiotic resistance and plasmid profiles of Salmonella enteritidis isolated from retail chicken meats. Am. J. Food Technol., 5: 260 268.

Mattick KL, Bailey RA, Jorgensen F, Humphrey TJ, 2002. The prevalence and number of Salmonella in sausages and their destruction by frying, grilling or barbecuing. J. Appl. Microbiol.,93: 541- 547.

Molla B, Alemayehu D, Salah W, 2003. Sources and distribution of Salmonella serotypes isolated from food animals, slaughterhouse personnel and retail meat products in Ethiopia, 19972002. Ethiop. J. Health, 17:63-70.

Neto $F$, Filho $P$, Barrow $P$, Junior BA, 2010. Sources of human non-typhoid salmonellosis: a review. Rev. Bras. Cienc. Avic., 12:1-11.

Onyeneho SN and Hedberg CW, 2013 : An Assessment of Food Safety Needs of Restaurants in Owerri, Imo State, Nigeria. Int. J. Environ. Res. Public Health , 10: 3296-3309.

Qiumei S, Yuan Z, Fang H, Chen C, Zhang Y, Wang Q, 2012. Situation of Salmonella Contamination in Food in Hebei Province of China from 2009 2010. J. Anim. Vet. Adv., 6: 746-749.

Redmond EC and Griffith CJ, 2003. Consumer food handling in the home: a review of food safety studies. J. Food Prot., 66:130-136.

Samiullah S, 2013. Salmonella Infantis, a Potential Human Pathogen has an Association with Table Eggs. Int. J. Poultry Sci., 12: 185-191.

Stojanović P, Babić T and Miljković-Selimović B, 2010. Salmonella enterica subspecies enterica serovar enteritidis - actualities and importance. Acta Medica Medianae, 49: 7175.

Thomas A, Lallo CH, Badric N, 2006. Microbiological evaluation of broiler carcasses, wash and rinse water from pluck shops (cottage poultry processors) in the county Narival/Mayaro, Trinidad, Trinidad and Tobago, West Indies. Tropicultura , 24: 135-142.

Vindigni SM, Srijan A, Wongstitwilairoong B , Marcus R, Meek J, Riley PL , 2007. Prevalence of food borne microorganisms in retail foods in Thailand. Foodborne Pathog Dis., 4 : 208-215.

WHO, 2004. Report on Typhoid fever in Democratic Republic of the Congo. www.who.int/csr/don I2004 12 15/en/ 15 December 2004. 